\title{
Note
}

\section{Correlation between Size of Body Parts (Particularly Mandibles) and Wet Body Weight in Aquatic Insects}

\author{
Hiromi Kofuji, Yu Isobe and Teizi Kawal
}

\begin{abstract}
We studied the mandible shapes of aquatic insects, and analyzed correlations between the wet body weight and the size of mandibles and other parts of six orders, 15 families commonly found in the Takami and Shigou Rivers in Higashiyoshino, Nara Prefecture. Highly significant correlations between the size of mandible and wet body weight of insects were obtained in all families studied. Since the mandibles of aquatic insects usually remain in the feces of the birds and the stomachs of fishes, and are easily identified by family name, the regression lines obtained in this study would be useful in estimating the amount of prey taken by animals.
\end{abstract}

Key words: aquatic insects, mandible size, body weight, correlation

\section{Introduction}

Aquatic insects are important prey for dippers (Cinclidae) which live along rivers (Cramp, 1988). In order to continuously study the insect diet of individual dippers without disturbing the birds, it is useful to identify the family name and size of the prey from body parts, particularly mouthparts, which remain in the feces of dippers. In most studies on the diet of dippers, food items have been identified only to the level of orders (Shaw, 1979; CrAmp, 1988; Eguchi, 1990). Ormerod (1985) and Ormerod and TYLER (1986) studied the correlations between dry weights and mandible width or length of some aquatic insect families. However, they used only right mandibles to estimate dry weight. Since mandibles are usually fragmented, it would be necessary to measure both width and length of both sides of the mandibles. In this study, we measured wet body weight and size of mandibles and other body parts in several families of aquatic insects commonly found in the Takami and Shigou Rivers. We then analyzed the correlation between wet body weight and size of body parts to reconstruct the wet weight of prey from the size of body parts in 15 families in 6 orders of aquatic insects. In addition, we described the diagnostic features of mandible shapes in some families of Ephemeroptera, Plecoptera and Trichoptera which are the most important in studying on the diet of Brown Dippers (Cinclus pallasii) by fecal analysis (Kofuj, unpublished).

\section{Materials and methods}

Aquatic insects on the stream bed were collected at four sites in the territorial area of the dippers. Two collection sites were set at the shallow depositional area and the riffle, respectively, in the Takami and Shigou Rivers, which are tributaries of the Yoshino River in Nara Prefecture (see the detailed description in BAN and KaWAI, 1986). The collections were made once a month in April and May 1985, and once or twice a month from September 1985 to March 1986. A $625 \mathrm{~cm}^{2}$ grid was dropped into the burn and the substrate collected, while an 1 $\mathrm{mm}$ mesh net was set up immediately downstream of the sampling site to gather animals 
disturbed by the collection of substrate. The substrate material was examined on a white tray, and all animals were collected and stored in $10 \%$ formalin.

The macro-invertebrates were identified by specific name, and the number of individuals were counted. The aquatic insects abundantly present were shown in Table 1. Each species was divided into three to five size-groups judged by visual inspection. Three individuals were randomly taken from each size-group, and the wet body weights of individual insects were measured with an autobalance (Mettler AE166). The heads of the insects were dissect ed, and the length and width of right and left mandibles were measured with a micrometer set in a binocular microscope. These mandibles were measured in three orders of aquatic insects (Ephemeroptera, Plecoptera and Tri- choptera except Glossosomatidae, Lepidostomatidae, and Leptoceridae). In some families of Trichoptera, head length and frontoclypeal apotome length were also measured. In Glossosomatidae, Lepidostomatidae, Leptoceridae, Aphelocheiridae, and Tipulidae, we took the dimensions of the head because the mandibles were too small to measure. In Coleoptera, the length of the side and centre of thoracic tergites (body width) was measured. Species and genera belonging to each family were shown in Table 1. The length and width of mandibles were measured at their maximum as indicated in Figure 1. Regression lines were calculated between wet body weight transformed to common logarithms and the size of body parts.

Table 1. Species and genera of aquatic insects and individual numbers used to make correlation equations of each family.

\begin{tabular}{|c|c|c|}
\hline Family & No. & Species and genera \\
\hline \multicolumn{3}{|l|}{ Ephemeroptera } \\
\hline Siphlonuridae & 12 & Ameletus spp. \\
\hline Baetidae & 18 & Baetis spp., Pseudocloeon japonica, Pseudocloceon spp. \\
\hline Heptageniidae & 19 & $\begin{array}{l}\text { Cynigma hirasana, Cynigma spp., Epeorus curvatulus, E. ikononis. } \\
\text { E. latifolium. E. uenoi. Epeonus spp. }\end{array}$ \\
\hline $\begin{array}{l}\text { Leptophlebiidae/ } \\
\text { Ephemerellidae }\end{array}$ & 36 & $\begin{array}{l}\text { Leptophlebia spp., Ephemerella japonica. E. rufa. E. nigra, E. basalis, } \\
\text { Ephemerella spp. }\end{array}$ \\
\hline Ephemeridae & 8 & Ephemera strigata, Ephemera spp. \\
\hline \multicolumn{3}{|l|}{ Plecoptera } \\
\hline Perlodidae/Perlidae & 20 & Stavsolus japonicus, Stavsolus spp., Oyamia lugubris, Oyamia spp. \\
\hline \multicolumn{3}{|l|}{ Hemiptera } \\
\hline Aphelocheiridae & 7 & Aphelocheirus vittatus \\
\hline \multicolumn{3}{|l|}{ Trichoptera } \\
\hline Stenopsychidae & 9 & Stenopsyche marmorata. S. sauteri. Stenopsyche spp. \\
\hline Hydropsychidae & 18 & Hydropsyche orientslis, H. setensis, Hydropsyche spp., Cheumatopsyche spp. \\
\hline Rhyacophiridae & 24 & $\begin{array}{l}\text { Rhyacophila yamakensis, } R \text {. transquilla, R. kisoensis, } R \text {. nigrocephala, } \\
\text { Rhyacophila spp. }\end{array}$ \\
\hline Glossosomatidae & 9 & Glossosoma inops, G. altaicum, Glossosoma spp. \\
\hline Lepidostomatidae & 9 & Goerodes spp. \\
\hline Leptoceridae & 9 & Ceraclea spp. \\
\hline \multicolumn{3}{|l|}{ Coleoptera } \\
\hline Psephenidae & 12 & Psephenoides spp., Mataeopsephus spp. \\
\hline \multicolumn{3}{|l|}{ Diptera } \\
\hline Tipulidae & 9 & Antocha spp. \\
\hline
\end{tabular}


a<smiles>CC1CCCCC1C</smiles>

b<smiles>CC1CCCCCCCCCCCCCCCCCC1</smiles>

c

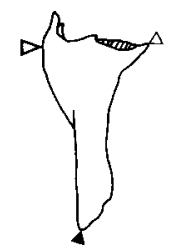

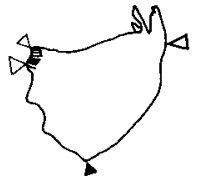
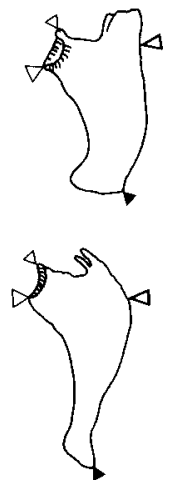

d
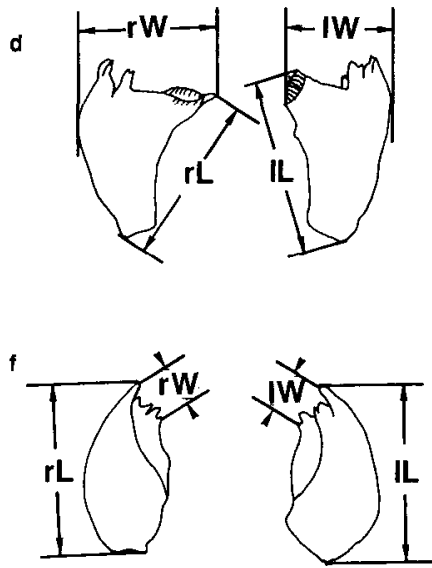
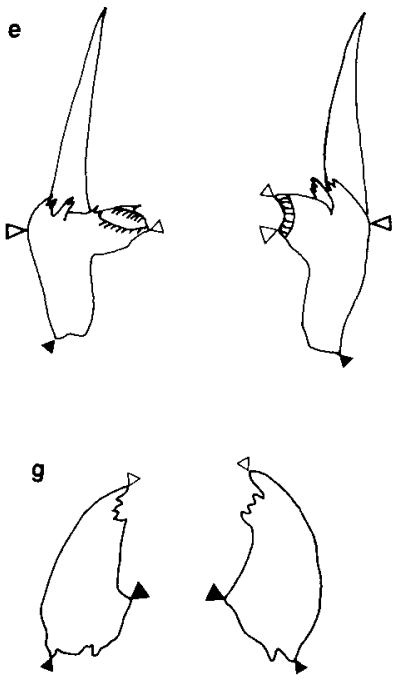

h
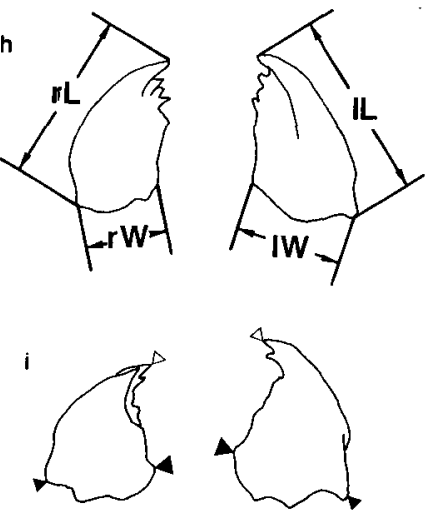

Fig. 1. Examples of ventral views of mandibles in each family. Length and width were mea sured. In the same order, the same dimensions were measured. In Ephemeroptera, $\mathrm{L}=$ length from the molar $(\triangleright)$ to root $(\triangleright), W=$ width from molar (at left $\triangleright$ ) to side $(?$ ). In Plecoptera, $\mathrm{L}=$ length from terminal (distal) incisor lobe of teeth to point of musculature articulation, $\mathrm{W}=$ width from terminal (distal) incisor lobe of teeth to basal (proximal) molar lobe of teeth. In Trichoptera, $L=$ length from point of teeth $(\triangleright)$ to root $(\checkmark), W=$ width of root $(--4)$. a, Siphlonuridae; b, Baetidae; c, Heptageniidae; d, Leptophlebiidae/Ephemerellidae; e, Ephemeridae; f, Perlodidae/Perlidae; g, Stenopsychidae; h, Hydropsychidae; i, Rhyacophilidae.

\section{Results}

3-1. Morphological diagnoses of mandibles in families of Ephemeroptera, Plecoptera, and Trichoptera

From the mandibular features, it was possible to identify the family name, but very difficult or almost impossible to identify the specific name. In the cases of Leptophlebiidae and Ephemereliidae in Ephemeroptera, and Perlodidae and Perlidae in Plecoptera, two families were amalgamated, since these families could not be dis- 
tingushed from one another by mandible shape.

\section{3-1-1. Ephemeroptera}

The insects in all families have distinct molar and incisors on the mandible with a wide distance between them (Fig. 1). The incisors of the left mandible are usually similar in shape to those of the right. The direction of molar surfaces on the two mandibles usually differs: The molar surface of the left mandible is situated somewhat parallel to the lateral margin of the mandible; that of the right is situated at a right angle to the lateral margin in dorsal view. Both the incisors and the molar surfaces are heavily sclerotized (Fig. 1).

\section{Siphlonuridae}

The mandibles are broad with two independent thin incisors. The incisors are located on the outer side of the mandible, and the outer incisors are serrated while the inner ones are not.

\section{Baetidae}

The mandibles are nearly square with broad and flattened incisors of both sides.

\section{Heptageniidae}

The mandibles are elongated. The incisors are thin and sharp, and have one blade.

\section{Leptophlebiidae/Ephemerellidae}

The mandibles are round, and have thicker chithin than those of other families. The incisors are irregularly serrated.

\section{Ephemeridae}

The mandibles have mandibular tusks, which are more or less circular in cross section. The molars and incisors are similar to those of Ephemerellidae.

\section{3-1-2. Plecoptera \\ Perlodidae/Perlidae}

The mandibles are very thin and strong, and bear multiple sharp apical teeth which are sometimes serrated on the inner surface. There is no appreciable development of the prosthecum. Both mandibles are similar in shape and have five teeth on the top. The ventral surface is concave.

\section{3-1-3. Trichoptera}

The mandibles are short and massive with a triangular base in the shape of a trigonal pyramid. The ventral side of the mandible is more or less flattened or somewhat convex, while the dorsal surface is concave. The distal end of the mandible is pointed. The blades of the right mandible are more irregular and sharper than those of the left. The ventral acitabularcondylar articulation of the left mandible is well developed.

\section{Stenopsychidae}

The mandibles are somewhat elongated. The blade has a knife ridge, and covers about one third of the inner concave margin.

\section{Hydropsychidae}

The mandibles are shorter than those of Stenosychidae. The blade has a knife ridge, and occupies half of the inner concave margin.

\section{Rhyacophilidae}

The mandibles closely resemble those of Hydropsychidae in general form. The blade is sharply pointed and has four teeth, the frontal one being larger and sharper than the other three.

3-2. Correlation between mandible size and wet body weight

Regression equations between wet body weight and each parameter of the mandible, head and body for each family were exhibited in Table 2. The correlation coefficients were very high in each dimension of all examined families. The slopes of all regressions are statistically significant $(P<0.05)$. In Ephemeroptera and Plecoptera, correlation coefficients were over 0.95 in most cases, whereas those of Trichoptera were very variable, and showed lower coefficient values compared with those of other groups. The correlation coeffi. cient of Rhyacophilidae in particular indicated the lowest value $(r=0.74)$.

There were some differences in linear regres. sions between right and left mandibles.

\section{Discussion}

Morphological diagnoses of mandibles in Figure 1 proved to be useful in identifying the family names of aquatic insects. Since the head and body shape of these insects have been reported (YAMAGISHI, 1977; KaWAI, 1985), descriptions of these body parts were excluded. As the shape of right and left mandibles differs, 
Table 2. Regressions between wet body weight and each parameter of parts with chitin. Abbreviations, $r L=$ length of right mandible, $r W=$ width of right mandible, $\mathrm{IL}=$ length of left mandible, $\mathrm{IW}=$ width of left mandible, $\mathrm{HL}=$ length of head, $\mathrm{HW}=$ width of head, $\mathrm{FL}=$ length of frontclypeal apotome, $\mathrm{BW}=$ half of width of body, No. =numbers of samples. Linear regression $y=b+a \times 10^{-4} x ; y=$ wet body weight (mg) (after log 10 transformation), $x=$ each parameter size $(\mu \mathrm{m}), a, b=$ invariables, $r=$ coefficient

\begin{tabular}{|c|c|c|c|c|c|c|c|c|c|c|c|c|c|c|c|c|c|}
\hline Family & & No. & $a$ & $b$ & $r$ & Family & & No. & $a$ & $b$ & $r$ & Family & & No. & $a$ & $b$ & $r$ \\
\hline \multirow{4}{*}{ Siphlonuridae } & $\mathrm{rL}$ & 12 & 31 & 1.42 & 0.97 & Baetidae & $\mathrm{rL}$ & 18 & 63 & 2.01 & 0.97 & Heptageniidae & $\mathrm{rL}$ & 18 & 28 & 1.33 & 0.97 \\
\hline & $\mathrm{rW}$ & 12 & 28 & 1.26 & 0.98 & & $\mathrm{rW}$ & 18 & 75 & 1.64 & 0.95 & & $\mathrm{rW}$ & 18 & 49 & 1.23 & 0.95 \\
\hline & $1 \mathrm{~L}$ & 11 & 29 & 1.28 & 0.95 & & $1 \mathrm{~L}$ & 18 & 57 & 1.95 & 0.96 & & IL & 19 & 26 & 1.29 & 0.98 \\
\hline & $1 \mathrm{~W}$ & 11 & 31 & 1.22 & 0.97 & & IW & 18 & 75 & 1.61 & 0.94 & & IW & 19 & 57 & 1.48 & 0.96 \\
\hline Leptophlebiidae/ & $\mathrm{rL}$ & 35 & 32 & 1.37 & 0.96 & Ephemeridae & $\mathrm{rL}$ & 8 & 17 & 0.12 & 0.92 & Perlodidae/ & $\mathrm{rL}$ & 20 & 12 & 0.09 & 0.95 \\
\hline \multirow[t]{3}{*}{ Ephemerellidae } & $\mathrm{rW}$ & 35 & 41 & 1.24 & 0.91 & & $\mathrm{rW}$ & 8 & 26 & 0.45 & 0.96 & Perlidae & $\mathrm{rW}$ & 20 & 27 & 0.21 & 0.95 \\
\hline & $\mathrm{IL}$ & 36 & 29 & 1.30 & 0.95 & & $1 \mathrm{~L}$ & 8 & 18 & 0.38 & 0.98 & & $1 \mathrm{~L}$ & 20 & 12 & 0.09 & 0.95 \\
\hline & IW & 36 & 49 & 1.30 & 0.96 & & $1 \mathrm{~W}$ & 8 & 24 & 0.16 & 0.91 & & IW & 20 & 27 & 0.23 & 0.96 \\
\hline \multirow[t]{6}{*}{ Stenopsychidae } & $\mathrm{rL}$ & 9 & 33 & 0.75 & 0.98 & Hydropsychidae & $\mathrm{rL}$ & 17 & 49 & 1.41 & 0.93 & Rhyacophilidae & $\mathrm{rL}$ & 24 & 39 & 1.11 & 0.74 \\
\hline & $\mathrm{rW}$ & 9 & 65 & 0.52 & 0.92 & & $\mathrm{rW}$ & 17 & 110 & 1.89 & 0.86 & & $\mathrm{rW}$ & 23 & 55 & 0.86 & 0.74 \\
\hline & IL & 9 & 32 & 0.70 & 0.97 & & $\mathrm{IL}$ & 17 & 46 & 1.30 & 0.91 & & IL & 24 & 38 & 1.17 & 0.83 \\
\hline & IW & 9 & 80 & 0.97 & 0.95 & & lW & 17 & 93 & 1.54 & 0.82 & & IW & 24 & 57 & 0.93 & 0.74 \\
\hline & $\mathrm{HL}$ & 9 & 5 & 0.31 & 0.98 & & $\mathrm{HL}$ & 18 & 20 & 1.46 & 0.90 & & $\mathrm{HL}$ & 24 & 16 & 1.16 & 0.82 \\
\hline & $\mathrm{FL}$ & 9 & 10 & 0.49 & 0.96 & & FL & 18 & 20 & 0.17 & 0.85 & & FL & 23 & 27 & 1.15 & 0.86 \\
\hline \multirow[t]{2}{*}{ Glossosomatidae } & $\mathrm{HL}$ & 9 & 41 & 2.15 & 0.96 & Lepidostomatidae & $\mathrm{HL}$ & 9 & 16 & 0.65 & 0.80 & Leptoceridae & $\mathrm{HL}$ & 9 & 14 & 0.58 & 0.86 \\
\hline & $\mathrm{FL}$ & 9 & 5 & 1.82 & 0.85 & & $\mathrm{FL}$ & 9 & 21 & 0.60 & 0.81 & & $\mathrm{FL}$ & 9 & 17 & 0.52 & 0.84 \\
\hline \multirow[t]{2}{*}{ Tipulidae } & $\mathrm{HL}$ & 9 & 32 & 1.80 & 0.92 & Aphelocheiridae & $\mathrm{HW}$ & 7 & 12 & 1.04 & 0.99 & Psephenidae & $\mathrm{BW}^{\prime}$ & 12 & 7 & 0.69 & 0.96 \\
\hline & HW & 9 & 46 & 1.98 & 0.84 & & & & & & & & & & & & \\
\hline
\end{tabular}

$P<0.05$ 
it is possible to count the exact number of prey from the mandibles remaining in dipper feces (KofusI, unpublished). In this paper, we reported four linear regressions on the width and length of mandibles of both sides in each family of aquatic insects. Both width and length of mandibles were necessary to estimate the body weight of insects for the following three reasons. (1) The mandibles of insects in feces are often fragmented. (2) In some cases, the mandibles of only one side are available. (3) In most families, the regressions on the parameters of right and left mandibles were different from one another.

By using the regression equations reported here, the quantity of aquatic insects eaten by dippers can be estimated from the size of mandibles in the fecal pellets of the dippers (KoFuJI, unpublished). When studying fish diet, we believe that these regression equations should prove useful in estimating the composition and quantity of aquatic insects from the stomach contents of the fishes.

\section{Acknowledgements}

We are grateful to Prof. Dr. Oishi for his kindness in giving us many suggestions and for reading this manuscript. The authors are also indebted to Prof. Dr. Nagoshr and Assoc. Prof. Dr. WADA of our univerisity for their valuable advice and encouragement.

\section{摘 要}

\section{水生昆虫の体サイズ（特に大腮サイズ）と 体湿重量の相関}

吉野川の支流である四鄉川と高見川においてよ くカワガラスの慨となっている水生昆虫の 6 目 15 科についての大腮, 頭および体の大きさと体湿重 量を測定し，それぞれの大きさと体湿重量の相関 を出した。15 科全てにおいて高い相関が得られた。 大照は水生昆虫を採食する鳥類の䔬中にもっとも 完全な形で残っており，科によって特徵的な形を
しており，また左右で形が違うことから翼に出て くる餌の同定や個体数の算定に便利である。鳥類 の糞中に残った水生昆虫の大腮や頭の大きさを測 定し, 得られた相関式を用いて元の慨となった水 生昆虫の大きさを復元することができる。

以上のことから, 相関式蜻水昆虫食の鳥や魚 の餌の量の推定に有效だと思われる。

\section{References}

BAN, R. and T. KawaI (1986): Comparison of the life cycles of two mayfly species between upper and lower parts of the same stream. Aquatic Insects, 8: 207-215.

CRamp, S. (1988): The Birds of the Western Palear. ctic, Vol. 5, Oxford University Press, Oxford.

EGuchi, K. (1990): The choice of foraging methods of the brown dipper, Cinclus pallasii (Aves: Cinclidae). J. Ethol., 8: 121-127.

Kawal, T. (1985): An Illustrated Book of Aquatic Insects of Japan. Toukaidaigakushuppan (in Japanese).

ORMEROD, S. J. (1985): The diet of breeding dippers Cinclus cinclus and their nestlings in the catch. ment of the River Wye, mid-Wales: a preliminary study by faecal analysis. Ibis, $127: 316^{-}$ 331.

Ormerov, S. J. and S. J. Tyler (1986): The diet of dippers Cinclus cinclus wintering in the catchment of the River Wye, Wales. Bird Study, 33: $36-45$.

Shaw, G. (1979): Prey selection by breeding dippers. Bird Study, 26: 66-67.

YAMAGISHI, T. (1977): Life history of the aquatic

- cranefly, Antocha bifida Alexander (Diptera: Tipulidae, Limoniinae). Nara Hydrobiol., 6: 121 (in Japanese).

(著者: 小藤弘美, 磯辺叻う, 奈良女子大学理学部 生物学教室, $\overline{\mathbf{T}} 630$ 奈良市北魚屋西町; 川合禎次, $\overline{\mathrm{T}}$ 606 京都市左京区岩倉南大蕗町 47-7; Hiromi KoFuJI and $\mathrm{Yu}$ Isobe, Department of Biology, Faculty of Science Nara Women's University, Kitauoya-nishimachi, Nara 630; Teizi KAWAI, Iwakura Minamiohsagi-cho 47-7, Sakyo-ku, Kyoto 606)

Received: 9 August 1991

Accepted: 4 December 1991 